\title{
Influence of Internal Organization Context on Strategy Implementation among Cooperative Societies in Nairobi County, Kenya
}

\author{
Angeline Kinya-Ogeto ${ }^{1}$, Mike Iravo Amuhaya ${ }^{2}$, John Kihoro ${ }^{3}$, Samuel Mokaya ${ }^{4}$ \\ ${ }^{1}$ Department of ETLM, School of Human Resource Development, Jomo Kenyatta University of Agriculture and \\ Technology, Kenya \\ ${ }^{2}$ Westlands Campus, Jomo Kenyatta University of Agriculture and Technology, Kenya \\ ${ }^{3}$ Directorate of Computing and e Learning (DCeL), Co-operative University of Kenya, Kenya \\ ${ }^{4}$ Arusha Campus, Jomo Kenyatta University of Agriculture and Technology, Kenya
}

\begin{abstract}
This study sought to determine the influence of the internal organizational context on strategy implementation among cooperative societies in Nairobi, Kenya. The study adopted a survey research design to collect data and a quantitative design for data analysis. The study covered a sample of 291 primary cooperative societies selected using a random sampling method from a population of 2,149 societies. Data was analyzed using descriptive and inferential statistics. Out of a sample of Two hundred and ninety-one sets of research instruments two hundred were filled and returned; representing a significant response rate of $68.73 \%$. Out of the 200 respondents, only 180 responding societies had formulated strategic plans and these were the only ones covered by the variable analysis (61.85\%). The study found a strong positive correlation between the internal organizational context and strategy implementation $(r=.674, n=180, p<.001)$. The study concludes that the major milestones of strategy implementation had not been achieved in most societies. Successful implementation of strategic plans in cooperative societies requires its organizational structure to be aligned to its strategic plan. It must also be flexible enough to be responsive to any environmental changes. The leadership must be strategic in their outlook, able to not only guide the people but also motivate them towards strategy implementation. Finally, the culture of the organization must be conducive to the strategy being implemented.
\end{abstract}

Key words: culture, Leadership, Organizational Structure, strategy implementation

\section{Introduction}

Strategy implementation is an important part of strategic management and indeed of management in general. Shah (1996) [1] maintains that Implementation is the process of translating strategic plans and policies into results. The most elegantly conceived, most precisely articulated strategy is virtually worthless unless it is implemented successfully. Several factors have been brought out as being responsible for poor implementation rate. The appendix to this paper brings out some of such factors as brought out by various authors over time. It is widely acknowledged that the implementation of a new strategy can be a difficult task; however, the true rate of failure is not known (Candido \& Santos 2015)[2] . This study looks at one such factor, internal organizational context. The internal organizational context consists of structure, leadership and culture. The internal conditions are many and varied depending on the organization. However, management has some strategic control over how these various internal conditions interact. The achievement of synergy in this process gives rise to competitive advantage. Examples include structural changes, strategic leadership and organizational culture. According to Hitt et al., (2007)[3] the resources are the sources of capabilities, some of which lead to development of the firm's core competences or its competitive advantage. Leadership is one such resource. External environments can create opportunities and threats for a firm but internal environmental conditions can turn these opportunities and threats to competitive advantage by using the organization's capabilities, unique resources and core competencies.

\section{Purpose Of The Study}

The purpose of this study was to determine the influence of internal organizational context on strategy implementation among primary cooperative societies in Nairobi County, Kenya. The study was guided by the following specific objectives;

i. To establish the influence of organizational structure on strategy implementation among cooperative societies in Nairobi, Kenya.

ii. To determine how leadership affects strategy implementation among cooperative societies in Nairobi, Kenya. 
iii. To assess the influence of organizational culture on strategy implementation among cooperative societies in Nairobi Kenya.

\section{Materials And Methods}

The study was conducted in Nairobi County; one of the 47 counties in the Republic of Kenya. The study used a descriptive survey design. Descriptive survey designs are used to allow for the gathering of information, summarize, present and interpret it for the purpose of clarification. According to Mugenda and Mugenda (2008)[4], descriptive studies are more formalized and typically structured with clearly stated hypotheses or investigative questions. This serves not only to describe the variables of interest but also to bring out any association between the variables and in particular between the dependent variable and the independent variable/(s).

The population for this study was obtained from a comprehensive list of registered cooperatives operating under the County Cooperative Commissioner (CCC) Nairobi. The study population was 2,149 primary cooperative societies. From this population a sample of 291 cooperative societies was selected using simple random sampling method. Quantitative data was analyzed using the Statistical Package for Social Science (SPSS). Descriptive and inferential statistical techniques were both employed to report the results. Confidence intervals and tests for statistical significance were set at the .05 level.

The study used a structured questionnaire to collect data directly from respondents at their workstations. The questionnaires were dropped and picked later. The survey utilized a Likert-type Scale with five options of response, ranging from "Strongly Disagree, Disagree, Neutral, Agree and Strongly Agree". Below is the key used in discussing the likert scale results;

\subsection{Likert Scale Key \\ Strongly Agree $4.2-5.0$ \\ Agree $\quad 3.4-4.2$ \\ Neutral $\quad 2.6-3.4$ \\ Disagree $\quad 1.8-2.6$ \\ Strongly Disagree $1.0-1.8$}

A panel composed of experts in the graduate committee and other specialists reviewed the questions for validity. Cronbach Alpha was used to test the reliability of the research instrument. Data analysis was done using both descriptive and inferential statistics. Pearson's Product Moment Correlation was used to test the relationship between each sub-factor and strategy implementation. Regression analysis was used to test the relationship between internal context and strategy implementation.

\subsection{Survey Participant's Characteristics}

\section{Results And Discussions:}

A total of 291 sets of research instruments were distributed to the sampled cooperative societies' leadership who were either supervisors or managers during the data collection exercise. Two hundred sets of questionnaires were filled and returned; representing a response rate of 68.73\%. Richardson (2005) indicates that the response rates of $60 \%$ or more is both desirable and achievable for a survey research. Of the 200 respondents, majority were $(46.5 \%)$ supervisors and almost half $(48 \%)$ had served for more than 5 years and thus they had the adequate work experience to implement their organization's strategic plans. Regarding the characteristics of the societies, $55.6 \%$ had been in existence for a period of less than 10 years. Out of the 200 respondents, only 180 or $61.85 \%$ had designed a strategic plan and were in the process of implementing it, while $65 \%$ had a capital base more than 50 million Kenyan shillings. The majority of the societies $(72.5 \%)$ had more than 50 employees and thus capable of implementing their plans. The data analysis proceeded on 180 respondents who had a strategic plan

\subsection{Organization Structure and Strategy Implementation}

Buchanan and Huczynski (2004) [5] defines organization structure as a formal system of task and reporting relationships that controls, co-ordinates and motivates employees so that they work together to achieve organizational goals. Bloisi (2007)[6] highlights importance of structure as a means of coordinating people to work towards common goals thus acting as facilitator in pursuit of organizational goals. Chandler Jr (2003)[7] proclaimed a maxim that has been followed as doctrine by strategists and consultants alike i.e. 'Structure follows Strategy'. Chandler showed that the need to re-organize or restructure is triggered by a strategic shift driven by new technologies or market changes. If an organization changes its strategy, it must change its structure to support the new strategy. If this does not happen, performance will be compromised. 
The relationship between strategy and structure was assessed through a set of statements where the respondents were asked to rate them on a scale of 1 to 5 , in which 1 meant strongly disagree and 5, strongly agree. Table 1.0 shows the relationship between strategy and structure among primary cooperative societies in Kenya. The results show that majority of the respondents agreed that most of the societies had a flexible structure (3.54), they were neutral on all other points. Rajasekar (2014)[8] in quoting Bayrami revealed that top management formulates strategy exclusively and middle-level managers only implement the strategy therefore a wide range of changes is required before implementation (structure alignment with strategy). The standard deviations were small $(1.453,1.164,1.1371 .298$ and 1.327 respectively), and thus indicated that the item responses were slightly varied.

Table 1: Relationship between organizational structure and strategy implementation

\begin{tabular}{|c|c|c|c|c|c|c|c|c|c|c|c|}
\hline \multirow[t]{2}{*}{ Statement/ item } & \multicolumn{2}{|c|}{$\begin{array}{l}\text { Strongly } \\
\text { Disagree }\end{array}$} & \multicolumn{2}{|c|}{ Disagree } & \multicolumn{2}{|c|}{ Neutral } & \multicolumn{2}{|c|}{ Agree } & \multicolumn{2}{|c|}{ Strongly Agree } & \multirow[t]{2}{*}{ Mean } \\
\hline & $\mathrm{Fq}$ & $\%$ & $\mathrm{Fq}$ & $\%$ & $\mathrm{Fq}$ & $\%$ & $\mathrm{Fq}$ & $\%$ & $\mathrm{Fq}$ & $\%$ & \\
\hline $\begin{array}{l}\text { The society is not designed to enable } \\
\text { speed of communication and } \\
\text { decision making }\end{array}$ & 31 & 17.2 & 68 & 37.8 & 10 & 5.6 & 32 & 17.8 & 39 & 21.7 & 2.89 \\
\hline $\begin{array}{l}\text { The society has a flexible structure } \\
\text { which allows it to make decisions } \\
\text { fast }\end{array}$ & 12 & 6.0 & 29 & 16.1 & 22 & $\begin{array}{l}12 . \\
2\end{array}$ & 83 & 46.1 & 34 & 18.9 & 3.54 \\
\hline $\begin{array}{l}\text { The middle level management is not } \\
\text { empowered to make decisions (e.g. } \\
\text { on resource allocation) that would } \\
\text { make them more efficient in their } \\
\text { assigned tasks. }\end{array}$ & 31 & 17.2 & 68 & 37.8 & 30 & $\begin{array}{l}16 . \\
7\end{array}$ & 45 & 25.0 & 6 & 3.3 & 2.59 \\
\hline $\begin{array}{l}\text { The strategic plan implementation } \\
\text { was poorly coordinated }\end{array}$ & 40 & 22.2 & 52 & 28.9 & 24 & $\begin{array}{l}13 . \\
3\end{array}$ & 50 & 27.8 & 14 & 7.8 & 2.70 \\
\hline $\begin{array}{l}\text { The society is not able to change its } \\
\text { power relations fast enough when } \\
\text { environmental changes demand that. }\end{array}$ & 31 & 17.2 & 39 & 21.7 & 17 & 9.4 & 73 & 40.6 & 20 & 11.1 & 3.07 \\
\hline
\end{tabular}

Source: Research Data, 2016

\subsection{Leadership and Strategy Implementation}

Leadership and especially strategic leadership is widely described as one of the key drivers of effective implementation, (Thompson \& Strickland 2003[9], Pearce and Robinson 2007[10] \& (Jooste and Fourie 2009)[11]. Arising from this observation, it can be said that lack of strategic leadership is a major barrier to strategy implementation. Effective leadership involves a lot of management; managing the people processes in the organisation so that people can align themselves to the strategy. Leaders are responsible for formulating and communicating the strategy but their responsibility doesn't stop there. They need to ensure that the people in the organisation understand the strategy, buy into it, and align their decisions and actions accordingly and this alignment needs to be measured and monitored.

The assessment of the influence of leadership on strategy implemetation involved a set of statements that the respondents were given and told to rate in a scale of 1 to 5 . Table 2.0 presents the relationship between leadership and strategy implementation. The results showed that respondents were agreed that the management were able to offer strong leadership (Mean=3.75). This is largely in line with the view of leadership that the leader plays a directive role and holds much influence over his followers (Bolden, 2004)[12]. Respondents were also agreed that leadership plays a key role in strategy implementation (Mean=3.91). The leadership of the cooperative societies was able to provide guidance on strategic issues based on the vision of the organization. The vision is the core of leadership and is at the heart of strategy. The leader's job is to create the vision for the enterprise in a way that will engage both the imagination and the energies of its people. Higgs \& Rowland (2005)[13] describe a leader as a shaper; one who personally controls what is done, sets the pace for others, and expects others to follow their example.

The results also show that most of the respondents disagreed with the statements that leadership offered by the top management did not inspire trust and loyalty among the staff members (Mean=2.54) and that the management through its action was unable to communicate its own commitment to strategy implementation (Mean=2.52). This means that management were able to inspire trust and loyalty and also that management was able to communicate its commitment to strategy implementation. They were however neutral on the statement that the top management empowered the middle and lower level managers to perform their role in strategy implementation (Mean=2.62). The standard deviations were as follows; 1.163, 1.202, 1.235, 1.178 and 1.270 respectively. This shows that the variation in the item responses was slight. 
Table 2.0: Relationship between leadership and strategy implementation

\begin{tabular}{|c|c|c|c|c|c|c|c|c|c|c|c|}
\hline \multirow[t]{2}{*}{ Statement/ item } & \multicolumn{2}{|c|}{$\begin{array}{l}\text { Strongly } \\
\text { Disagree }\end{array}$} & \multicolumn{2}{|c|}{ Disagree } & \multicolumn{2}{|c|}{ Neutral } & \multicolumn{2}{|c|}{ Agree } & \multicolumn{2}{|c|}{ Strongly Agree } & \multirow[t]{2}{*}{ Mean } \\
\hline & $\mathrm{Fq}$ & $\%$ & $\mathrm{Fq}$ & $\%$ & $\mathrm{Fq}$ & $\%$ & $\mathrm{Fq}$ & $\%$ & $\mathrm{Fq}$ & $\%$ & \\
\hline $\begin{array}{l}\text { The organization's leadership is able } \\
\text { to provide strong leadership to the } \\
\text { organization on strategic issues }\end{array}$ & 14 & 7.8 & 15 & 8.3 & 21 & $\begin{array}{l}1 \\
1 . \\
7\end{array}$ & 83 & $\begin{array}{l}46 . \\
1\end{array}$ & 47 & 26.2 & 3.75 \\
\hline $\begin{array}{l}\text { The leadership offered by the top } \\
\text { management does not inspires trust } \\
\text { and loyalty among the staff members }\end{array}$ & 40 & $\begin{array}{l}22 . \\
2\end{array}$ & 64 & $\begin{array}{l}35 . \\
6\end{array}$ & 19 & $\begin{array}{l}1 \\
0 . \\
6\end{array}$ & 52 & $\begin{array}{l}28 . \\
9\end{array}$ & 5 & 2 & 2.54 \\
\hline $\begin{array}{l}\text { The management through its action } \\
\text { is unable to communicate its own } \\
\text { commitment to strategy } \\
\text { implementation }\end{array}$ & 40 & $\begin{array}{l}22 . \\
2\end{array}$ & 70 & $\begin{array}{l}38 . \\
9\end{array}$ & 20 & $\begin{array}{l}1 \\
1 . \\
1\end{array}$ & 38 & $\begin{array}{l}21 . \\
1\end{array}$ & 12 & 6.7 & 2.51 \\
\hline $\begin{array}{l}\text { The top management does not } \\
\text { empower middle and lower level } \\
\text { managers to perform their role in } \\
\text { strategy implementation }\end{array}$ & 30 & $\begin{array}{l}16 . \\
7\end{array}$ & 72 & $\begin{array}{l}40 . \\
0\end{array}$ & 23 & $\begin{array}{l}1 \\
2 . \\
8\end{array}$ & 46 & $\begin{array}{l}25 . \\
6\end{array}$ & 9 & 5.0 & 2.62 \\
\hline $\begin{array}{l}\text { Leadership plays a key role in } \\
\text { strategic plan implementation in the } \\
\text { cooperative society }\end{array}$ & 20 & $\begin{array}{l}11 . \\
1\end{array}$ & 9 & 5.0 & 6 & $\begin{array}{l}3 . \\
3\end{array}$ & 77 & $\begin{array}{l}42 . \\
8\end{array}$ & 68 & 37.8 & 3.91 \\
\hline
\end{tabular}

Source: Research Data, 2016

\subsection{Organizational Culture and Strategy Implementation}

Organizational culture includes the shared beliefs, norms and values within an organization. It sets the foundation for strategy. For a strategy within an organization to develop, mature and be implemented successfully, it must fully align with the organizational culture. Thus, initiatives and goals must be established within an organization to support and establish an organizational culture that embraces the organization's strategy over time. That is, a culture that systematically supports strategy implementation and fosters a culture of partnership, unity, teamwork and cooperation among employees. Organizations that remain flexible are more likely to embrace change and create an environment that remains open to production and communication. This provides a model that welcomes cultural diversity and helps clarify strategy implementation. Culture within an organization can serve many purposes, including unifying members within an organization and help create a set of common norms or rules within an organization that employees follow.

The study assessed the culture of cooperative societies through a set of statements measured using a 5 likert scale in which 1 meant strongly disagree and 5, strongly agree. As shown in Table 3.0, The respondents agreed that the organization's environment was conducive to strategy implementation (Mean=3.48). They were however neutral on all other points. Mintzberg (2004)[14] argues that a good implementation of strategic plan is dependent on the learning and development environment for employees who are the true foot soldiers of implementation. The item standard deviations were small and included; 1.334, 1.187, 1.147, and 1.281 respectively, meaning there was not much variation in item responses from the mean.

Table 3.0: Relationship between organizational culture and strategy implementation

\begin{tabular}{|c|c|c|c|c|c|c|c|c|c|c|c|}
\hline \multirow[t]{2}{*}{ Statement/ item } & \multicolumn{2}{|c|}{$\begin{array}{l}\text { Strongly } \\
\text { Disagree }\end{array}$} & \multicolumn{2}{|c|}{ Disagree } & \multicolumn{2}{|c|}{ Neutral } & \multicolumn{2}{|c|}{ Agree } & \multicolumn{2}{|c|}{ Strongly Agree } & \multirow[t]{2}{*}{ Mean } \\
\hline & $\mathrm{Fq}$ & $\%$ & $\mathrm{Fq}$ & $\%$ & $\mathrm{Fq}$ & $\%$ & $\mathrm{Fq}$ & $\%$ & $\mathrm{Fq}$ & $\%$ & \\
\hline $\begin{array}{l}\text { The strategic plan implementation } \\
\text { disturbs the norms and practices of } \\
\text { the cooperative society }\end{array}$ & 15 & 8.3 & 53 & $\begin{array}{l}29 . \\
4\end{array}$ & 21 & 11.7 & 47 & $\begin{array}{l}26 . \\
1\end{array}$ & 44 & 24.4 & 3.27 \\
\hline $\begin{array}{l}\text { The management failed to address } \\
\text { employees' short term concerns or } \\
\text { reservations about the new strategy }\end{array}$ & 26 & $\begin{array}{l}14 . \\
4\end{array}$ & 63 & $\begin{array}{l}35 . \\
0\end{array}$ & 24 & 13.3 & 60 & $\begin{array}{l}33 . \\
3\end{array}$ & 7 & 3.9 & 2.87 \\
\hline $\begin{array}{l}\text { The society does not have to use } \\
\text { detailed rules and procedures to } \\
\text { enforce discipline and cooperation } \\
\text { among the junior employees }\end{array}$ & 21 & $\begin{array}{l}11 . \\
7\end{array}$ & 49 & $\begin{array}{l}27 . \\
2\end{array}$ & 41 & 22.8 & 55 & $\begin{array}{l}30 . \\
6\end{array}$ & 14 & 7.8 & 3.03 \\
\hline $\begin{array}{l}\text { The organizational environment is } \\
\text { conducive to the implementation of } \\
\text { its strategic plan }\end{array}$ & 18 & $\begin{array}{l}10 . \\
0\end{array}$ & 27 & $\begin{array}{l}15 . \\
0\end{array}$ & 18 & 10.0 & 76 & $\begin{array}{l}42 . \\
2\end{array}$ & 41 & 22.8 & 3.48 \\
\hline
\end{tabular}

Source: Research Data, 2016

\subsection{Hypothesis Testing}

HO: The internal environmental context has no significant effect on strategy implementation among the primary cooperative societies in Nairobi, Kenya.

A Pearson product-moment correlation was run to determine the relationship between internal environment and strategy implementation. There was a strong, positive, correlation between internal environment and strategy 
implementation that was statistically significant $(r=.674, \mathrm{n}=180, \mathrm{p}<.001)$ as shown in Table 4.0. The findings are in line with those of the previous studies, for instance, Hrebiniak and Joyce (1984)[15] stated that everything depends upon everything else in strategy implementation and that there should therefore be harmony among the key implementation factors. A whole range of questions can be directed at practicing managers concerning how harmony can be achieved and maintained. Some sample questions for managers and executives may include whether the environment fits the strategy, culture and structure, or whether the proposed decision fits the organizational structure, culture, resources and people. Thompson et al, (2006)[16] relate good strategy execution to strong fits between strategy and organizational capabilities, reward structure, internal operating systems and the organization's work climate and structure.

Table 4.0: Relationship between internal organizational context and strategy implementation

\begin{tabular}{|l|l|l|l|}
\hline Variables & Internal environment & Strategic plan Implementation \\
\hline Internal environment & Pearson Correlation & 1 & $.674^{* *}$ \\
\cline { 2 - 4 } & Sig. (2-tailed) & & .000 \\
\cline { 2 - 4 } & $\mathrm{N}$ & 180 & 180 \\
\hline \multirow{3}{*}{ Strategic plan Implementation } & Pearson Correlation & $.674^{* *}$ & 1 \\
\cline { 2 - 4 } & Sig. (2-tailed) & .000 & 180 \\
\cline { 2 - 4 } & $\mathrm{N}$ & 180 & \multicolumn{2}{l}{} \\
\hline
\end{tabular}

Source: Research Data, 2016

\subsection{Strategy Implementation}

According to the findings (Table 5.0) most of the respondents agreed that the strategic plan implementation exceeded the resources initially budgeted for it (Mean=3.42), clearly indicating a lack of success in the area of budget performance. Respondents were neutral on all other areas, indicating that respondents could not clearly state whether the level of strategy implementation among their cooperative societies was successful or not.

Table 5.0: Level of strategy implementation in cooperative societies in Nairobi

\begin{tabular}{|c|c|c|c|c|c|c|c|c|c|c|c|}
\hline \multirow[t]{2}{*}{ Statement/ item } & \multicolumn{2}{|c|}{$\begin{array}{l}\text { Strongly } \\
\text { Disagree }\end{array}$} & \multicolumn{2}{|c|}{ Disagree } & \multicolumn{2}{|c|}{ Neutral } & \multicolumn{2}{|c|}{ Agree } & \multicolumn{2}{|c|}{ Strongly Agree } & \multirow[t]{2}{*}{ Mean } \\
\hline & $\mathrm{Fq}$ & $\%$ & $\mathrm{Fq}$ & $\%$ & $\mathrm{Fq}$ & $\%$ & $\mathrm{Fq}$ & $\%$ & $\mathrm{Fq}$ & $\%$ & \\
\hline $\begin{array}{l}\text { The strategic plan has not been translated } \\
\text { into operational plan(s) and targets }\end{array}$ & 16 & 8.9 & 51 & 28.3 & 17 & 9.4 & 52 & 28.9 & 44 & 24.4 & 3.28 \\
\hline $\begin{array}{l}\text { The strategic plan implementation has not } \\
\text { been tied to the annual objectives. }\end{array}$ & 30 & 16.7 & 66 & 36.7 & 21 & 11.7 & 56 & 31.1 & 5 & 2.8 & 2.66 \\
\hline $\begin{array}{l}\text { The operational outcome expected from } \\
\text { the strategic plan has not been achieved }\end{array}$ & 21 & 11.7 & 46 & 25.6 & 38 & 21.1 & 62 & 34.4 & 10 & 5.6 & 3.03 \\
\hline $\begin{array}{l}\text { Performance targets have not been tied to } \\
\text { the strategic plan }\end{array}$ & 18 & 10.0 & 60 & 33.3 & 27 & 15.0 & 62 & 34.4 & 13 & 7.2 & 2.91 \\
\hline $\begin{array}{l}\text { Performance rewards are not tied to } \\
\text { strategic plan implementation }\end{array}$ & 22 & 12.2 & 51 & 28.3 & 20 & 11.1 & 74 & 41.1 & 13 & 7.2 & 3.08 \\
\hline $\begin{array}{l}\text { The achievement of the strategic plan } \\
\text { objectives is lagging behind schedule }\end{array}$ & 25 & 13.9 & 36 & 20.0 & 32 & 17.8 & 71 & 39.4 & 16 & 8.9 & 3.10 \\
\hline $\begin{array}{l}\text { The financial outcome expected from the } \\
\text { strategic plan has not been or being } \\
\text { achieved }\end{array}$ & 22 & 12.2 & 45 & 25.0 & 31 & 17.2 & 67 & 37.2 & 15 & 8.3 & 3.02 \\
\hline $\begin{array}{l}\text { The strategic plan implementation } \\
\text { exceeded the resources initially budgeted } \\
\text { for it }\end{array}$ & 9 & 5.0 & 31 & 17.2 & 26 & 14.4 & 96 & 53.3 & 18 & 10.0 & 3.42 \\
\hline $\begin{array}{l}\text { Strategy implementation is not a regular } \\
\text { agenda in management meetings }\end{array}$ & 19 & 10.6 & 47 & 26.1 & 31 & 17.2 & 66 & 36.7 & 17 & 9.4 & 2.97 \\
\hline $\begin{array}{l}\text { Strategy implementation is not a regular } \\
\text { agenda in governance meetings }\end{array}$ & 30 & 16.7 & 56 & 31.1 & 22 & 12.2 & 62 & 34.4 & 10 & 5.6 & 3.04 \\
\hline $\begin{array}{l}\text { The annual budget of the society is not } \\
\text { tied to strategic objectives of the society }\end{array}$ & 17 & 9.4 & 51 & 28.3 & 31 & 17.2 & 70 & 38.9 & 11 & 6.1 & 2.87 \\
\hline $\begin{array}{l}\text { The society has not kept track of its } \\
\text { strategy implementation }\end{array}$ & 23 & 12.8 & 64 & 35.6 & 20 & 11.1 & 55 & 30.6 & 18 & 10.0 & 2.87 \\
\hline $\begin{array}{l}\text { The major milestones of strategy } \\
\text { implementation have not been achieved }\end{array}$ & 22 & 12.2 & 45 & 25.0 & 31 & 17.2 & 67 & 37.2 & 15 & 8.3 & 3.02 \\
\hline $\begin{array}{l}\text { strategy implementation has been } \\
\text { successful in the society }\end{array}$ & 7 & 3.9 & 19 & 10.6 & 49 & 27.2 & 81 & 45.0 & 24 & 13.3 & 3.38 \\
\hline
\end{tabular}

Source: Research Data, 2016

\section{Conclusion}

The paper can conclude that organizational structure, leadership and culture are individually positively correlated to strategy implementation and that internal environmental context has an influence on strategy implementation among the cooperative societies. In the case of the sampled cooperative societies, the only positive factor that the societies had was a strong supportive leadership offered by their management. The importance of leadership in strategy implementation is supported by Stata (1988)[17], who avers that after 
articulating the vision of where a company is headed, the Chief Executive Officer (CEO) must monitor progress toward the vision by focusing attention on the quality of the process and the key indicators of organizational performance. The respondents were also of the opinion that the cultures of their various organizations were conducive to strategy implementation. Cristian-Liviu (2013) [18] avers that culture is supportive to strategy when it is dynamic and actively influences members to take initiative in formulating and implementing strategy.

The structures were however generally not conducive to strategy implementation. Although they had flexibility for decision-making, the respondents were neutral on virtually all other points. Rajasekar (2014)[8], states that many studies have addressed the link between organization strategy and structure and point out that one of the challenges in Strategy Implementation is weak coordination of activities. The respondents are therefore unable to categorically state whether overall strategy implementation in their societies was successful. The authors wish to acknowledge that indeed there are several other factors (outside the scope of this paper), which have been said to have an influence in strategy implementation. These must have compounded the net effect on the success or otherwise of the strategy implementation. The paper is useful to strategic management practitioners in bringing out some of the relevant areas in implementing strategy. Furthermore, it is useful for strategy researchers in stimulating academic interest in strategy implementation. One such area is trying to determine and test other factors relevant to strategy implementation.

\section{Recommendations}

- On the internal environmental context, societies should come up with structures, which are flexible enough to allow quick decision-making. Such flexibility is enhanced by structures that empower the middle level managers to make decisions directly affecting their work. This will increase the flexibility of the organization in responding to opportunities and even threats in their operating environments.

- The leadership should be committed to strategy implementation and supportive of all the staff in achieving effective strategy implementation.

- On the other hand, societies must understand and work within the existing organizational culture in trying to achieve strategy implementation. Where the culture is not supportive of the strategy implementation, steps must be taken to change the culture.

[1]. Shah A M (1996) Strategy Implementation: A Study of Critical Factors Indian Journal of Industrial Relations and Human Resources Vol 32, No. 1(Jul. 1996), pp 42-55

[2]. Candido J F C \& Santos P S (2015) Strategy Implementation: What is the failure rate? Journal of Management and Organization 21(2) 237-262 Feb 2015 DOI 10.1017/jmo.2014.77

[3]. Hitt, M. \& Hoskisson, R. \& Ireland, R. 2007, Management of Strategy. Thomson South-Western. International Student Edition

[4]. Mugenda, O., \& Mugenda, A. (2008). Research Methods - Quantitative and Qualitative Approaches. Nairobi: ACTS Press.

[5]. Pearce J A II \& Robinson R B. (2007) Strategic Management: formulation, implementation and control Boston, Mass, London: McGraw Hill/Irwin

[6]. Buchanan, D., \& Huczynski, A., (2004). Organizational Behaviour. An Introductory Text. 5th Edition. Essex: Prentice Hall.

[7]. Bloisi, W., (2007). Management and Organizational Behaviour. 2nd European Edition. London: McGraw-Hill Companies.

[8]. Chandler A D Jr (2003) Chapters in the History of the American Industrial Enterprise BeardBooks, Washington DC ISBN 1-58798198-X

[9]. Rajasekar J (2014) Factors affecting effective Strategy Implementation in a service Industry: A Study of Electricity Distribution Companies in the Sultanate of Oman International Journal of Business and Social Science Vol 5 no. 9(1) August 2014

[10]. Thompson A A Jr \& Strickland A J (2003) Strategic Management: Concepts and cases McGraw Hill/Irwin 2003

[11]. Pearce J A \& Robinson R B (2007) Strategic Management: Formulation, Implementation and Control Boston: Mcgraw Hill/Irwin

[12]. Jooste C \& Fourie B (2009) The role of Strategic Leadership in effective strategy implementation: Perceptions of South African Strategic leaders South African Business Review Vol 13(3) 2009

[13]. Bolden, R. (2004). What is leadership? Leadership South West Research Report. Exeter: University of Exeter, Centre for Leadership Studies.

[14]. Higgs, M., \& Rowland, R. (2005). All changes great and small: exploring approaches to change and its leadership. Journal of Change Management, 5 (2), 121-151

[15]. Mintzberg H (2004) Managers, Not MBAs: A Hard look at the Soft Practice of Managing and Management Development BerretKoehler publishers 2004

[16]. Hrebiniak, L. and Joyce, W. (1984). Implementing Strategy. New York: MacMillan

[17]. Thompson, A., Strickland, A., Gamble, J., Jain, A. (2006). Crafting and Executing Strategy: The Quest for Competitive Advantage. New Delhi: Tata McGraw Hill.

[18]. Stata R (1988) The Role of the Chief Executive Officer in articulating the vision The Institute of Management Sciences 00912102/88/1803/0003\$01.25Cristian-Liviu (2013) Organizational culture and Strategy. How does it work? http://steneconomiceuoradea.ro/anale/volume/2013/n1/180 22nd March 2017 